\title{
National Action Plans: Current Status and Future Prospects for a New Business and Human Rights Governance Tool
}

\author{
Claire METHVEN O'BRIEN,* Amol MEHRA,** Sara BLACKWELL,*** and \\ Cathrine Bloch POULSEN-HANSEN****
}

Keywords: corporate accountability, governance, human rights, national action plans, UN Guiding Principles on Business and Human Rights

\section{INTRODUCTION}

National Action Plans (NAPs) on business and human rights are a burgeoning phenomenon. In 2011, the European Union (EU) requested member states to develop NAPs to support implementation of the UN Guiding Principles on Business and Human Rights (UNGPs) ${ }^{1}$ and, in 2014, the UN Human Rights Council (UNHRC) followed suit. $^{2}$ Prompted by these and other initiatives, a steadily increasing number of governments and non-state actors have now launched NAPs or NAPs-related processes: more than forty are underway across Europe, the Americas, Africa, and Asia. ${ }^{3}$

This emerging trend is to be welcomed. ${ }^{4}$ Every NAP process affirms the UNGPs' essential tenet that human rights apply within the business sector and indicates a political commitment to bring domestic laws, policies, and practices into alignment with this norm. Just four years after the arrival of the UNGPs, this is an impressive and significant result for a soft law instrument.

\footnotetext{
* Strategic Adviser, Human Rights and Development Department, Danish Institute for Human Rights (DIHR); Research Fellow, Department of International Law, University of Groningen.

** Director, International Corporate Accountability Roundtable (ICAR).

*** Legal and Policy Co-ordinator, Frameworks Programmes, ICAR.

**** Advisor and Corporate Engagement Programme Manager, Human Rights and Development, DIHR.

1 European Commission, 'A Renewed EU Strategy 2011-14 for Corporate Social Responsibility', COM (2011) 681 final (25 October 2011), http://eur-lex.europa.eu/LexUriServ/LexUriServ.do?uri=COM:2011:0681:FIN:en:PDF (accessed 14 August 2015).

2 Human Rights Council, 'Human Rights and Transnational Corporations and Other Business Enterprises', A/HRC/RES/ 26/22 (15 July 2014), http://daccess-dds-ny.un.org/doc/UNDOC/GEN/G14/083/82/PDF/G1408382.pdf?OpenElement (accessed 14 August 2015).

3 Office of the High Commissioner for Human Rights, 'State National Action Plans', http://www.ohchr.org/EN/ Issues/Business/Pages/NationalActionPlans.aspx (accessed 14 August 2015).

4 This trend also deserves further scholarly attention in terms of norm diffusion, the role of transnational human rights networks, and multi-level human rights governance. See, e.g., Thomas Risse et al (eds.), The Persistent Power of Human Rights: From Commitment to Compliance (Cambridge: Cambridge University Press, 2013).
} 
Yet, amongst advocates, there are concerns. To date, individual NAPs have been largely declaratory of existing measures and commitments, with few hard promises to take new action. ${ }^{5}$ We remain far from a 'tipping point' in terms of business behaviour. ${ }^{6}$ Thus, the question remains: by which means can the greatest, and quickest, improvements in business respect for human rights be achieved?

The UNHRC passed two resolutions in 2014, signalling two different possible responses to this question. One reaffirmed the UNGPs and called, amongst other things, for states to develop NAPs. ${ }^{7}$ The second resolved to establish an intergovernmental process on the human rights obligations of transnational corporations that, many hope, may lead to an international treaty providing for a legally enforceable right to remedy for business-related human rights abuses. ${ }^{8}$

Although views remain sharply divided on the merits, legal, and political viability of such an instrument, scarcely any voice has been raised to suggest that the UNGPs should be abandoned entirely. With the negotiation of any treaty likely to take years, how best to promote the UNGPs' implementation meanwhile remains a salient question. Consequently, we suggest, NAPs should now be a topic for sustained analysis and advocacy within the business and human rights field.

\section{A BRIEF History of NAPs}

\section{A. NAPs: The Basics}

NAPs are government-drafted policy documents that articulate state priorities and indicate future actions to support implementation of legal obligations or policy commitments on a given topic. Before being applied to business and human rights, NAPs were already in use in other relevant policy areas, including human rights in general ${ }^{9}$ and corporate social responsibility (CSR). ${ }^{10}$

NAPs may be viewed as a soft law, 'new governance' tool. ${ }^{11}$ As such, they may promote convergence of state practice towards achievement of goals or standards where consensus on the need for legal obligations, or what their content should be, is lacking, or

\footnotetext{
5 Recent studies suggest that new measures are needed particularly to ensure access to effective remedy for business-related human rights abuses. See, e.g., Gwynne Skinner et al, The Third Pillar: Access to Judicial Remedies for Human Rights Violations by Transnational Business (2013), http://icar.ngo/wp-content/uploads/2013/02/TheThird-Pillar-Access-to-Judicial-Remedies-for-Human-Rights-Violation-by-Transnational-Business.pdf (accessed 14 August 2015).

6 See, e.g., Claire Methven O'Brien and Sumithra Dhanarajan, 'The Corporate Responsibility to Respect Human Rights: A Status Review' (forthcoming, 2016) Accounting, Auditing, and Accountability Journal, http://papers.ssrn.com/sol3/papers.cfm?abstract_id=2591226 (accessed 14 August 2015).

7 Human Rights Council, note 2.

8 Human Rights Council, 'Elaboration of an International Legally Binding Instrument on Transnational Corporations and Other Business Enterprises with Respect to Human Rights', A/HRC/RES/26/9 (14 July 2014), http://daccess-ddsny.un.org/doc/UNDOC/GEN/G14/082/52/PDF/G1408252.pdf?OpenElement (accessed 14 August 2015).

9 DIHR and ICAR, National Action Plans on Business and Human Rights: A Toolkit for the Development, Implementation, and Review of State Commitments to Business and Human Rights Frameworks (2014) 8-10, http:// www.humanrights.dk/files/media/dokumenter/udgivelser/DIHR\%20-\%20ICAR\%20National\%20Action\%20Plans\%20 \%28NAPs\%29\%20Report.pdf (accessed 14 August 2015).

10 Ibid.

11 For an explanation of 'new governance' in the European Union see, e.g., Joanne Scott and David M. Trubek, 'Mind the Gap: Law and New Approaches to Governance in the European Union' (2002) 8(1). European Law Journal 1.
} 
where universal solutions to complex problems are hard to formulate. ${ }^{12}$ Peer review processes may be established in association with NAPs or similar instruments to foster sharing and evaluation of information amongst states, for instance, on the basis of a common framework, benchmarks, or indicators. ${ }^{13}$

\section{B. Business and Human Rights NAPs: Origins and Evolution}

The European Commission's 2011 'Communication on CSR' asked EU member states to produce NAPs on business and human rights by the end of 2012 , following a request to develop CSR NAPs. ${ }^{14}$ In 2012, the European Council's 'Strategic Framework on Human Rights and Democracy' repeated this call, extending the target date to the end of $2013 .{ }^{15}$

Amidst these developments, the European Network of National Human Rights Institutions (ENNHRI) issued the first set of written recommendations on business and human rights NAPs in 2012. In its 'Discussion Paper', ENNHRI identified both process and content requirements for business and human rights NAPs and urged the adoption of a human rights-based approach to their development, emphasizing criteria such as inclusion, transparency, participation, and accountability. ${ }^{16}$

A small number of EU governments quickly launched NAPs processes. In 2013, the United Kingdom ${ }^{17}$ and the Netherlands ${ }^{18}$ published the results of these efforts, followed by Denmark ${ }^{19}$ and Finland ${ }^{20}$ in 2014 and Lithuania in $2015 .^{21}$

Alongside, civil society groups and national human rights institutions (NHRIs) increased their focus on NAPs. In 2013, the Danish Institute for Human Rights (DIHR)

12 Ryan Goodman and Derek Jinks, 'Acculturation of States: The Theoretical Model' in Socializing States: Promoting Human Rights Through International Law (Oxford: Oxford University Press, 2013) Ch. 3.

13 See, e.g., European Commission, 'Corporate Social Responsibility in the EU', http://ec.europa.eu/social/main.jsp? catId=331 (accessed 14 August 2015); OECD, 'The OECD's Peer Review Process: A Tool for Co-Operation and Exchange', http://www.oecd.org/site/peerreview (accessed 14 August 2015).

14 'The Commission invites Member States to develop or update ... their own plans or national lists of priority actions to promote CSR ... [and] [i]nvites EU Member States to develop ... national plans for the implementation of the UN Guiding Principles'. European Commission, note 1, 13-14.

15 Council of the European Union, 'EU Strategic Framework on Human Rights and Democracy' (25 June 2012), https://www.consilium.europa.eu/uedocs/cms_data/docs/pressdata/en/foraff/131181.pdf (accessed 14 August 2015).

16 European Group of National Human Rights Institutions, 'Implementing the UN Guiding Principles on Business and Human Rights: Discussion Paper on National Action Plans for EU Member States' (2012), http://businesshumanrights.org/en/pdf-implementing-the-un-guiding-principles-on-business-and-human-rights-discussion-paper-onnational-implementation-plans-for-eu-member-states (accessed 14 August 2015).

17 Government of the United Kingdom, Foreign \& Commonwealth Office, 'Good Business: Implementing the UN Guiding Principles on Business and Human Rights' (2013), https://www.gov.uk/government/uploads/system/uploads/ attachment_data/file/236901/BHR_Action_Plan_-_final_online_version_1_.pdf (accessed 14 August 2015).

18 Government of the Netherlands, Ministry of Foreign Affairs, 'National Action Plan on Business and Human Rights' (2013), http://business-humanrights.org/sites/default/files/documents/netherlands-national-action-plan.pdf (accessed 14 August 2015).

19 Government of Denmark, 'Danish National Action Plan: Implementation of the UN Guiding Principles on Business and Human Rights' (2014), http://www.ohchr.org/Documents/Issues/Business/NationalPlans/Denmark_ NationalPlanBHR.pdf (accessed 14 August 2015).

20 Government of Finland, Ministry of Employment and Economy, 'National Action Plan for the Implementation of the UN Guiding Principles on Business and Human Rights' (2014), http://www.tem.fi/files/41214/TEMjul_ 46_2014_web_EN_21102014.pdf (accessed 14 August 2015).

21 Government of the Republic of Lithuania, 'Lithuania's Action Plan on the Implementation of the United Nations Guiding Principles on Business and Human Rights' (2015), http://www.ohchr.org/Documents/Issues/Business/ NationalPlans/Lithuania_NationalPlanBHR.pdf (accessed 14 August 2015); Italy and Spain published draft NAPs in 2014, and seven other EU Member States have indicated that they have begun NAPs processes. Office of the High Commissioner for Human Rights, note 3. 
and the International Corporate Accountability Roundtable (ICAR) launched a project to develop guidance and criteria to ensure that NAP processes and outcomes align with human rights standards. ${ }^{22}$ Informed by consultations with nearly 300 representatives of governments, civil society, NHRIs, and business across world regions, ${ }^{23}$ the result was a NAPs 'Toolkit' published in June 2014. ${ }^{24}$

The United Nations (UN) Working Group on Business and Human Rights held an open consultation on NAPs, ${ }^{25}$ followed by an expert workshop, ${ }^{26}$ in February and May 2014, respectively. The UNHRC called on states to develop NAPs in a June 2014 resolution, and the UN Working Group published its draft guidance in December 2014. ${ }^{27}$ The UN Global Compact published a guidance document on NAPs in $2015 .^{28}$ At regional level, the Council of Europe's (CoE) draft 'Recommendation on Human Rights and Business' included, by 2014, a call for the development of NAPs. ${ }^{29}$

Parallel to these developments, a second wave of NAPs processes has gained momentum. Over twenty European NAPs processes are underway. ${ }^{30}$ In the Americas, NAPs processes are ongoing in Chile ${ }^{31}$ and Colombia, ${ }^{32}$ and the governments of Argentina and Brazil have indicated a commitment to develop NAPs. The US

22 ICAR and DIHR, 'ICAR-DIHR National Action Plans Project', Business \& Human Rights Resource Centre, http:// business-humanrights.org/en/un-guiding-principles/implementation-tools-examples/implementation-by-governments/by-typeof-initiative/national-action-plans/icar-dihr-national-action-plans-project (accessed 14 August 2015) DIHR and ICAR.

23 ICAR and DIHR, 'ICAR-DIHR National Action Plans Project: Dialogues Briefing' (2014), http://icar.ngo/ wp-content/uploads/2014/05/NAPs-Project-Dialogues-Briefing.pdf (accessed 14 August 2015).

24 DIHR and ICAR, note 9.

25 Office of the High Commissioner for Human Rights, '2014 Sessions of the Working Group on the Issue of Human Rights and Transnational Corporations and Other Business Enterprises', http://www.ohchr.org/EN/Issues/Business/ Pages/2014Sessions.aspx (accessed 14 August 2015).

26 Ibid.

27 UN Working Group on Business and Human Rights, 'Guidance on National Action Plans on Business and Human Rights: Version 1.0’ (2014), http://www.ohchr.org/Documents/Issues/Business/UNWG_\%20NAPGuidance.pdf (accessed 14 August 2015); Centre for Applied Legal Studies, University of the Witwatersrand, Johannesburg, 'CALS Selected by UN Working Group,' (21 November 2013), http://www.wits.ac.za/academic/clm/law/cals/ newsitems/201311/22181/news_item_22181.html (accessed 14 August 2015).

28 The Global Compact, 'Guidance for Global Compact Local Networks on National Action Plans on Business and Human Rights' (2015), https://www.unglobalcompact.org/docs/issues_doc/human_rights/Resources/GCLN_National_ Action_Plan_Guidance.pdf (accessed 14 August 2015).

29 Council of Europe, Steering Committee for Human Rights, Drafting Group on Human Rights and Business, 'Draft Recommendation of the Committee of Ministers to Member States on Human Rights and Business', CDDH-CORP (2014)10 (22 August 2014), http://www.coe.int/t/dghl/standardsetting/hrpolicy/Other_Committees/HR_and_Business/ Documents/CDDH-CORP\%20Draft\%20Recommendation\%20Human\%20Rights\%20and\%20Business\%20Final\%20 ENG.pdf (accessed 14 August 2015). In June 2014, the Organization of American States (OAS) passed a resolution promoting the practical application of the UNGPs and calling on member states and their respective NHRIs to make concrete commitments in the area of business and human rights. However, this resolution stopped short of an explicit mention of NAPs. Organization of American States, Promotion and Protection of Human Rights in Business, AG/RES. 2840 (XLIV-O/14) (4 June 2014), http://www.oas.org/en/sla/dil/docs/AG-RES_2840_XLIV-O-14.pdf (accessed 14 August 2015).

30 For example, NAPs processes are in progress in Germany, Ireland, Belgium, Scotland, and Slovenia. Office of the High Commissioner for Human Rights, note 3.

31 In April 2015, a public launch took place and an inter-ministerial working group was established. 'Plan de Acción Nacional de Derechos Humanos y Empresas', http://www.derechoshumanosyempresas.gob.cl/ (accessed 14 August 2015). A national baseline study is being simultaneously undertaken by the Human Rights Programme of the University Diego Portales. Centro de Derechos Humanos, Universidad Diego Portales, 'Judith Schönsteiner lidera equipo que efectuará primer estudio línea base sobre empresas y derechos humanos en Latinoamérica', http://www. derechoshumanos.udp.cl/derechoshumanos/index.php/noticias-ddhh/item/1320-judith-schoensteiner-lidera-equipo-queefectuara-primer-estudio-linea-base-sobre-empresas-y-derechos-humanos-en-latinoamerica (accessed 14 August 2015). 32 The Colombian Government has a set of business and human rights policy guidelines intended to lay the foundation for a NAP. Office of the High Commissioner for Human Rights, note 3. 
government launched its NAP process in September 2014, with multistakeholder consultations taking place during $2015 .^{33}$

In Africa, the governments of Mozambique and Tanzania have committed to develop NAPs. Civil society groups or NHRIs have initiated studies or other activities to support progress towards a NAP process in Ghana, Morocco, South Africa, and Zambia, amongst others. ${ }^{34}$ In Asia, Malaysia's NHRI has published a 'Strategic Framework on a National Action Plan on Business and Human Rights for Malaysia' and the Malaysian government has undertaken to lead development of a NAP. ${ }^{35}$ The Philippines' NHRI and CSOs in Kazakhstan are respectively taking steps to encourage NAPs processes. ${ }^{36}$

\section{Pros and Cons of NAPs}

NAPs have a range of potential merits. ${ }^{37}$ Their development can trigger government commitments to implement business and human rights standards, so delivering better 'vertical' alignment of national laws, policies, and institutional practices with international commitments, strengthening the rule of law and, ultimately, greater human rights effectiveness. ${ }^{38}$

Such impacts could perhaps be expected from any national human rights policy initiative. As a result of their distinctively broad framing, however, NAPs processes should encourage the cross-government participation needed to secure 'horizontal' policy coherence. ${ }^{39}$ Moreover, if processes for developing NAPs follow human rights-based approaches and methodologies, other benefits should accrue. Adopting principles such as transparency, inclusion, participation, and non-discrimination in the production of NAPs should empower rights-holders and generate space for dialogue and greater mutual understanding between stakeholders. ${ }^{40}$ If NAPs include clear and evidence-based targets, milestones, and indicators, they ought additionally to provide a basis for holding governments to account and over time doing so on a comparative basis with other countries.

A more sceptical view of NAPs' value may however be taken. Some, indeed, view NAPs as a convenient fig leaf for governments' reluctance to adopt policies that might be construed as putting business at a competitive disadvantage, or as a forum in which corporate lobbying will trounce meaningful progress under the banner of 'multistakeholderism'. ${ }^{41}$ As a result, some consider NAPs processes as a waste of

33 Ibid.

34 Office of the High Commissioner for Human Rights, note 3; ICAR, 'ICAR Partners with LHRC, CHR, \& Khulumani to Support the Development of National Action Plans on Business \& Human Rights in Tanzania \& South Africa', http://icar.ngo/analysis/icar-partners-with-lhrc-chr-khulumani-to-support-the-development-of-naps-in-tanzaniasouth-africa/ (accessed 14 August 2015).

35 'National Action Plan on Business and Human Rights to Be Drafted', The Rakyat Post (24 March 2015 ), http://www.therakyatpost.com/news/2015/03/24/national-action-plan-on-business-and-human-rights-to-be-drafted/ (accessed 14 August 2015).

36 Office of the High Commissioner for Human Rights, note 3.

37 DIHR and ICAR, note 9.

38 Ibid.

39 Human Rights Council, 'Guiding Principles on Business and Human Rights: Implementing the United Nations "Protect, Respect and Remedy" Framework', A/HRC/17/31 (21 March 2011), http://www.ohchr.org/Documents/ Publications/GuidingPrinciplesBusinessHR_EN.pdf (accessed 14 August 2015).

40 DIHR and ICAR, note 9, 23.

41 ICAR and DIHR, note 22. 
resources which would be better invested in corporate 'naming and shaming' or advocacy for 'hard' law measures in areas like non-financial reporting or mandatory due diligence. $^{42}$

\section{Evaluating NAPs}

In this section, we present a tentative review of NAPs praxis to date across a range of countries, highlighting areas of strength and weakness with reference to six criteria advanced in the DIHR-ICAR NAPs Toolkit. ${ }^{43}$

\section{A. NAPs Praxis}

\section{Scope, Content, and Priorities}

The risk of harm to human rights cuts across all business activities. Coverage of the full range of the UNGPs, all human rights, and domestic as well as extraterritorial issues, is thus critical to a NAP's integrity and value. The UK, Dutch, Danish, and Finnish NAPs all feature an explicit commitment to the full scope of the UNGPs. At the same time they include discussion of thematic and sector-specific human rights issues. $^{44}$ The UK NAP, for example, considers procurement and investment agreements. $^{45}$

A prospect of concern, on the other hand, would be for governments to seek to restrict the scope of NAPs $a b$ initio to address only harms occurring in the domestic sphere, harms occurring abroad, or specific industry sectors, for example. While policies or efforts focused on high-risk industries or vulnerable groups may be warranted, curtailing the scope of a NAP from the outset is self-defeating. Only a '360 degrees' stocktaking can yield the horizontal and vertical policy coherence the UNGPs call for. By the same token, if NAPs commit only to 'voluntary' approaches, and not 'hard law' or 'regulatory' ones, it is unlikely they will achieve the regulatory 'smart mix' needed to deliver change on the ground. Based on published NAPs, this is a real risk: measures to expand access to legal remedies for victims, are scarcely mentioned, for example. ${ }^{46}$

\section{Baseline Assessments}

Given the broad scope of the UNGPs, a baseline assessment is important to ensuring that a NAP's content addresses existing gaps in protection, and hence to ensuring the NAP's relevance and credibility. No NAP published so far has followed on from a national baseline assessment (NBA) as such. ${ }^{47}$ An 'internal mapping' on the legal and policy

\footnotetext{
42 Ibid.

43 DIHR and ICAR, note 9, Ch. 6.

44 ICAR and European Coalition for Corporate Justice, 'Assessments of Existing National Action Plans (NAPs) on Business and Human Rights' (2014) 3, http://accountabilityroundtable.org/wp-content/uploads/2014/10/ICAR-ECCJAssessments-of-Existing-NAPs.pdf (accessed 14 August 2015).

45 Ibid, 8.

46 ICAR and ECCJ, note 44, 3. As one example, the Dutch NAP addresses neither non-voluntary measures with respect to Pillar I of the UNGPs, nor measures to support access to judicial remedy under Pillar III. Ibid, 13.

47 ICAR and ECCJ, note 44, 3.
} 
landscape was undertaken in the Netherlands, and a background memorandum was prepared by the government in Finland, but neither could be considered a comprehensive baseline assessment. ${ }^{48}$ Practice is fast changing in this area, however, with a number of governments extending support to NBAs as part of NAPs processes. ${ }^{49}$ In Germany, the NHRI produced a baseline assessment using the DIHR-ICAR NAPs Toolkit as a formal input to the German government's NAP process. ${ }^{50}$ In Chile, a university is developing a baseline, also using the Toolkit, to feed into the NAP process and which will integrate regional human rights standards into the analysis. ${ }^{51}$ The Scottish Government has commissioned an NBA, following a commitment to develop a business and human rights NAP made in the context of Scotland's general national human rights action plan process. ${ }^{52}$

\section{Consulting Stakeholders}

States should seek inputs from stakeholders in developing NAPs to help them identify priority business and human rights issues for their country, in terms, for example, of actual or potential severity of abuses in which businesses operating or domiciled in the jurisdiction may be implicated, and their level of incidence. Where needed, states should provide capacity building to facilitate effective, as opposed to merely notional, participation, especially by disempowered or at-risk rightsholders, as well government and business personnel lacking prior knowledge of business and human rights.

All NAPs processes to date have involved some form of multistakeholder consultation. For example, extensive interviews with business, civil society, and 'implementing organizations' were undertaken during the Dutch NAP process. ${ }^{53}$ NAP processes in Ireland and Chile were launched with a multistakeholder conference followed by a public call for input. ${ }^{54}$ Before starting to draft its NAP, the French government sought a formal opinion on its content from the French NHRI, itself a body composed of representatives drawn from across stakeholder categories. ${ }^{55}$ However, the level of transparency and inclusiveness of such consultation processes has varied. In Denmark, for example, the government did not publicly communicate a clear process for

48 Ibid.

49 Business and Human Rights Resource Centre, 'National Action Plans', http://business-humanrights.org/en/unguiding-principles/implementation-tools-examples/implementation-by-governments/by-type-of-initiative/nationalaction-plans (accessed 14 August 2015).

50 Business and Human Rights Resource Centre, 'Germany: German Institute for Human Rights Presents Baseline Assessment for Natl. Action Plan on Business \& Human Rights' (6 May 2015), http://business-humanrights.org/en/ germany-german-institute-for-human-rights-presents-baseline-assessment-for-natl-action-plan-on-business-human-rights (accessed 14 August 2015).

51 Universidad Diego Portales, note 31.

52 'What is SNAP?,' Scotland's National Action Plan for Human Rights (accessed 30 July 2015), http://www. scottishhumanrights.com/actionplan (accessed 14 August 2015).

53 Ibid.

54 Department of Foreign Affairs and Trade, 'Business and Human Rights - DFAT Call for Input' (12 January 2015), https://www.dfa.ie/news-and-media/press-releases/press-release-archive/2015/january/business-and-human-rights/ (accessed 14 August 2015).

55 Commission Nationale Consultative des Droits de l'Homme, 'Business and Human Rights: Opinions on the Issues Associated with the Application by France of the United Nations' Guiding Principles' (24 October 2013), http:// business-humanrights.org/en/pdf-business-and-human-rights-opinion-on-the-issues-associated-with-the-application-byfrance-of-the-united-nations-guiding-principles (accessed 14 August 2015). 
stakeholder consultation, ${ }^{56}$ while dedicated support for participation by disempowered or at-risk rightsholders has so far been absent across the board. ${ }^{57}$

\section{Transparency}

Information about the NAP process, the results of the NBA, the contents of the NAP, and arrangements for co-ordination of implementation and reporting should be public and transparent. This is because stakeholders require access to such information in order to participate meaningfully in NAPs dialogue and follow-up.

A lack of full transparency has been an issue across all NAP processes to date. For example, the UK and Finnish governments declined to provide summary reports of stakeholder consultations and information regarding the political process for approval of their NAPs. Obscuring from view how inputs received may have influenced the final outcome may weaken trust amongst stakeholders, as well as between stakeholders and the government. ${ }^{58}$

\section{Accountability}

A NAP should explicitly identify which government entity is responsible for its implementation, as well as for delivery of specific NAP commitments. It should also provide for cross-government involvement in development and roll-out and establish dedicated monitoring and reporting mechanisms or alternatively integrate the NAP into existing ones, if appropriate. Clear allocation of responsibility for NAPs commitments matters because, without it, stakeholders are stymied in engagement with governments and in holding them to account. Reporting by governments on NAPs and their impacts, on the other hand, is critical to an iterative process of learning and improvement about business and human rights challenges and how to address them.

Most NAPs could improve in this area. The UK, Dutch, Danish, and Finnish NAPs explicitly identify the government entities responsible for the NAP. ${ }^{59}$ Only Finland's NAP, however, allocates all commitments to specific ministries, while the Dutch, Danish, and UK NAPs do this in restricted areas. The UK and Finnish NAPs include information on how the commitments made will be implemented and monitored; the Dutch and Danish NAPs, by contrast, omit information on monitoring arrangements.

A pertinent question in this context is whether, if there is a lead agency, it has the authority needed to secure achievement of the NAP's goals. In the UK, Dutch, Danish, and Finnish processes, ${ }^{60}$ leadership was invested in foreign affairs ministries or in tradefocused units within enterprise ministries, despite the obvious need for NAPs to address business-related human rights impacts at home, as well as abroad, ${ }^{61}$ and a perception by

\footnotetext{
56 ICAR and ECCJ, note 44, 13.

57 Ibid, 3.

58 Ibid, 16.

59 ICAR and ECCR, note 44, 3.

60 Ibid.

61 American Federation of Labor and Congress of Industrial Organisations, 'Letter to President Obama Regarding US NAP' (12 December 2014), http://www.aflcio.org/content/download/146721/3757941/Letter+to+President+Obama +regarding+NAP.pdf (accessed 14 August 2015).
} 
stakeholders that foreign ministries, acting alone, lack sufficient authority to 'carry the argument' across government. Another relevant issue is the establishment of mechanisms for cross-government co-ordination and dialogue during and after NAPs development. The UK and Dutch governments set up inter-ministerial working groups as part of their NAP processes. ${ }^{62}$ However, in most cases, involvement of national legislatures in NAPs development, oversight, and accountability has been, so far, weak to non-existent, representing a significant missed opportunity to enhance NAPs' democratic legitimation.

\section{Resources}

Sufficient resources, in light of each country's relative size and budget, must be allocated to support a NAP's preparation, consultation, and follow-up phases, including provision for development of an NBA and for stakeholder consultation in relevant formats, and for production and dissemination of reports on the NAP's implementation.

To date, no government has published its NAPs budget or an implementation timeline ${ }^{63}$ whereas stakeholders have noted the inadequacy of resources during the NAP process as well as to support follow-through on NAPs' promised measures.

\section{NAPs: The NeXt ChAPTER}

Momentum around NAPs on business and human rights is increasing. Yet states' current NAPs practices comprise positive and concerning aspects in almost equal measure. Looking ahead, what can be done to ensure that the future trajectory is one of improvement, and to speed up progress ${ }^{64}$ We have identified three key factors.

First, more states must initiate NAPs. Here a top priority must be securing delivery of NAPs by those EU member states that have failed to meet previous deadlines. Beyond Europe, the African Union, OAS, and ASEAN, and more of their members, need to move first to words and then to action, in promoting and supporting NAPs processes. Regional organizations could consider, as those in Europe have done, ${ }^{65}$ encouraging states to develop and share information on NAPs through high-level statements or soft law instruments. They, as well as international agencies, donor organizations, and governments of countries that already have NAPs, should offer support to governments and national human rights actors seeking to engage in NAPs processes in the form of peer support or resources for technical assistance, according to local needs and preferences. Where they are not already a priority concern, NHRIs and CSOs should consider moving NAPs up their advocacy agendas.

Second, review and follow-up mechanisms should be established to support states in their production, implementation, and reporting on NAPs and to provide a forum where governments can be held to account for commitments made within them. A NAPs review could potentially take place at regional level, international level, or indeed on both levels

62 Ibid, 7-9.

63 ICAR and ECCJ note 44, 9.

64 Six criteria for effective NAPs were proffered in the DIHR-ICAR Toolkit. DIHR and ICAR, note 9, p. 40.

65 European Commission, note 1; Council of the European Union, note 15; Council of Europe, note 29. 
in parallel. ${ }^{66}$ Within the UN, such a process might be established by a Human Rights Council resolution, and could be marshalled by the UN Working Group on Business and Human Rights. While international or regional instruments could provide a solid basis for such processes, this should by no means be seen as prerequisite. Any group of interested states could convene a review for participation by interested parties. States that have already published NAPs should be encouraged to try this as soon as possible as a pilot exercise building on peer processes in other areas.

Third, policy makers and advocates must recognize NAPs as integral to, and not isolated from, the broader human rights and business landscape. NAPs processes provide a platform for the critical review of existing regulatory approaches on business and human rights, as well as for dialogue about policy innovations, across different geographical contexts. NAPs can thus help to generate information about alternative policy options for encouraging or requiring due diligence, corporate human rights reporting, and on enhancing access to legal remedy as well as the political, economic, legal, and regulatory factors influencing the success or failure of such approaches in practice. Such information constitutes invaluable 'raw data' which can only serve to enrich the careful analysis and evaluation of options needed both by policy makers at national level, and in the setting of the recently-established intergovernmental working group on a business and human rights treaty. ${ }^{67}$ Finally, given that intergovernmental process puts a spotlight on state efforts, or lack thereof, as well as highlighting the defaults of business enterprises, real opportunities may be presented via NAPs to lobby for stronger local measures on business and human rights which advocates should be alert to seize.

66 DIHR and ICAR, note 9, Ch. 7.

67 Office of the High Commissioner for Human Rights, 'Open-Ended Intergovernmental Working Group on Transnational Corporations and Other Business Enterprises with Respect to Human Rights', http://www.ohchr.org/EN/ HRBodies/HRC/WGTransCorp/Pages/IGWGOnTNC.aspx (accessed 14 August 2015). 